A Journal for Language Learning Tydskrif vir Taalaanleer

\title{
THE IMPACT OF ADDITIONS IN SHONA AND ENGLISH CONSECUTIVELY- INTERPRETED RAPE TRIALS IN ZIMBABWEAN COURTROOMS
}

\author{
Paul Svongoro \\ University of the Witwatersrand
}

This article investigates the conflict between interpreters' ethical guidelines and the reality in Zimbabwean courtrooms. Although court interpreters' instructions generally prescribe verbatim translations of original utterances, the reality in the courtroom may demand deviation from what the guidelines prescribe. Focusing on the effect of emphasising and down-toning additions on source language texts in four consecutively-interpreted rape trials heard in Shona and English, this study reveals that court interpreters are aware that their primary goal is to ensure that participants fully understand each other's intentions. Interpreters therefore adopt a strategy for conveying renditions which would ensure that a speaker's communicative intention, and not only his/her words, is available to an end receiver. The resultant renditions would nevertheless reveal some additions which may impact on the propositional content and style of the source message and hence the administration of justice. I therefore argue that interpreted courtroom dialogues are essentially 'three-party' (Mason, 2000: 9) face-to-face transactions involving two primary speakers and one interpreter.

\section{Keywords}

Ethical guidelines, court reality, content, style, emphasising, down-toning

\section{INTRODUCTION}

This article examines the conflict between interpreters' ethical guidelines prescribed by Hoffman (1994: 13) and the reality of the courtroom. Hoffman's (1994: 14) guidelines generally state that ' $[\mathrm{t}] \mathrm{he}$ interpreter must interpret faithfully-without addition or omissioneverything said in court'. The guidelines instruct interpreters to provide verbatim translations of original utterances 'using the same words and phrases, whenever this is possible'. However, when faced with the reality of the courtroom, interpreters deviate from this mechanistic way of interpreting (see, e.g., Mason, 2000; Moeketsi, 1999). The article thus analyses the effect of additions on the 'propositional content' (Thomas, 1995: 69) and style of source language (SL) texts in four consecutively-interpreted rape trials heard in Shona and English in Zimbabwean courtrooms.

In order to investigate what exactly happens when interpreters are faced with a situation when their objective of successful interaction is threatened by attention to official guidelines, the study was guided by the following hypotheses:

(1) Court interpreters' verbal behaviour reflects their preoccupation with enabling successful communication in the courtroom. 
(2) As a result of this concentration, court interpreters' target language (TL) texts would contain a variety of emphasising and down-toning additions.

In other words, the article hypothesised that the primary goal of court interpreters is successful interaction. Court interpreters are aware that, in order for this goal to be achieved, participants have to fully understand each other's 'intentions' (Sperber \& Wilson, 1986: 66). To achieve this, court interpreters avoid providing merely verbatim versions of speakers' SL utterances, as these would not bring about such understanding as end receivers 'unfamiliar with the context' of the interaction would not be able to fully infer speaker meaning (Feltoe, 1993: 17). In order to compensate for the differences in inferencing abilities of end receivers, interpreters adopt a strategy for conveying SL utterances which would ensure that a speaker's communicative intention, and not only his/her actual words, is available to an end receiver. The resultant TL texts will contain additions, some of which have an emphasising effect on the SL utterances while others have a down-toning effect.

\section{THE DATA}

The data for this study are four question/answer transcripts of English and Shona consecutively-interpreted rape trials heard at two magistrates' courts in Zimbabwe - Harare and Mutare. The transcripts were recorded and transcribed between October 2013 and March 2014. The recordings were transcribed verbatim, using a modified version of Du Bois' (1993) and Jefferson's (2002) transcription conventions of conversation analysis.

The transcription was intended to represent the speech in as detailed and multifaceted a manner as possible so as to provide the readers with an accurate representation of the interaction and thus included such non-verbal elements as pauses, emphases and overlapping speech. The researcher also considered the readability of the transcripts, as too many details and information could have made the transcripts difficult to read. Efforts were thus made to strike a balance between an accurate representation of the speech and readability of the transcripts. By the time the transcripts were complete, a total of 45 pages of transcripts, or 2533 turns, totalling 35197 words had been yielded. To save time and costs, the four transcripts are trials at different stages of the trial procedure. This was done so that the transcribed trials were as representative of the various stages of the trial procedure as possible.

\section{METHOD AND CONCEPTUAL FRAMEWORK}

In order to test the two hypotheses presented earlier, the article attempts to answer the following research questions:

(1) Are interpreters' TL texts verbatim of the SL messages or contain some additions?

(2) If the interpreters' TL texts include some additions, how could they be classified?

(3) Would the additions suggest court interpreters' motives for including the identified additions in the TL texts?

After recording and transcribing interpreted question-answer interactions in the four trials referred to above, the first research question was answered by conducting a SL/TL comparison of the collected data to identify any additions in the court interpreters' TL texts. 
The second research question was answered by grouping the identified additions according to their impact on the propositional content and style of the SL text. This enabled the researcher to establish categories of additions. When the categories of additions were established, the third research question was then answered by applying to the investigated interaction the pragmatic theory of conversational implicature, which was proposed by Herbert Grice (1975). The theory provides a framework for analysing 'how hearers infer speaker meaning' in the context of the participation framework provided by Erving Goffman (1981). The various strategies that a court interpreter may be assumed to resort to when confronted with implicature in an original utterance were then discussed. Finally, by using Grice's theory within Goffman's participation framework, certain conclusions regarding the interpreters' motives for including the identified additions were reached.

\section{FINDINGS}

The additions identified were observed to have a substantial impact on the propositional content and style of the source text and were classified into two broad categories: emphasising additions and down-toning additions, as explained below.

\section{Emphasising additions}

Additions in this category serve to emphasise, or increase the force of the utterance or part of the utterance, in the source text. The interpreter adds emphasis by including items which were not present in the SL text, either explicitly or implicitly, or by stressing one or more items in the interpreter's TL text which were not stressed in the SL text. These additions were subcategorised as follows:

Emphasising with the absolute negative 'never'

Table 1: Emphasising with 'never'

\begin{tabular}{|l|l|l|}
\hline Speaker & SL utterances/Interpretations & English gloss \\
\hline I & $\begin{array}{l}\text { Waudza dare muno kuti } \\
\text { pandakadzoka ndakakuti uuye mu } \\
\text { bedroom mangu Ndakadaro here ini } \uparrow\end{array}$ & $\begin{array}{l}\text { You have already testified in court that } \\
\text { when I came back I asked you to come to } \\
\text { my bedroom. Did I ask you to do so? }\end{array}$ \\
\hline W & Kwete & No \\
\hline I & I NEVER said anything like that & \\
\hline
\end{tabular}

Instead of simply rendering the SL message as simply 'No', the interpreter rendered it as '...never said anything like that', which the interpreter perceived to be underlying in the original utterance. The rendition includes the absolute negator 'never' (Horn, 2010) which slightly changes the style in which the utterance is made. The inclusion of 'never' potentially strengthens the witness's credibility (by emphasising denial in absolute terms), which may impact on the outcome of the trial. 
Table 2: Emphasising with 'never'

\begin{tabular}{|c|c|c|}
\hline Speaker & SL utterances/Interpretations & English gloss \\
\hline $\mathbf{A}$ & $\begin{array}{l}\text { Do you recall yourself saying that the } \\
\text { child complained that her leg had been } \\
\text { dragged or touched } \uparrow\end{array}$ & \\
\hline $\mathbf{I}$ & $\begin{array}{l}\text { Muchiri kutondera muchiti mwana } \\
\text { akati akanzwa seaidhonzwa kana } \\
\text { kubatwa gumbo } \uparrow\end{array}$ & $\begin{array}{l}\text { Do you remember telling the court that } \\
\text { your child felt as if her was leg was } \\
\text { being dragged or touched? }\end{array}$ \\
\hline $\mathbf{W}$ & Kwete haana kusvika achidaro & $\begin{array}{l}\text { No, the child did not say so when she } \\
\text { came to me }\end{array}$ \\
\hline I & $\begin{array}{l}\text { NO she never mentioned something } \\
\text { relating to her leg being dragged or } \\
\text { touched }\end{array}$ & \\
\hline
\end{tabular}

The explanation given for the example in Table 1 also applies for Table 2 above. The addition of the negative marker 'never' in the interpreter's rendition in Table 2 could be argued to be an interpreter's strategy for making the SL speaker's intentions (i.e. denial) available, or more available, to end receivers in line with Grice's (1975) theory of conversational implicature, which provides a framework for analysing how hearers infer speaker meaning.

\section{Emphasising with the form of address 'Your Worship'}

Emphasising additions below were attributed to the inclusion of the politeness form of address 'Your Worship' in the TL texts. This feature could first be attributed to the adversarial courtroom setting characterised by power asymmetry (Cotterill, 2003; Gibbons, 1993) between court players which may have a bearing on the interpreter's performance and to what O'Barr (1982) refers to as 'powerless speech style' which might also be expected to produce a positive or negative impression of the testifying witness or defendant.

As illustrated in Tables 3 and 4 below, the politeness forms and hyperformality evidenced by the use of the form of address 'Your Worship' in the TL texts emphasises and enhances the witness's image in terms of 'convincingness and trustworthiness' (Berk-Seligson, 2002).

Table 3: The form of address 'Your Worship'

\begin{tabular}{|l|l|l|}
\hline Speaker & SL utterances/Interpretations & English gloss \\
\hline $\mathbf{P}$ & $\begin{array}{l}\text { The following morning did you go to } \\
\text { school }\end{array}$ & \\
\hline $\mathbf{I}$ & $\begin{array}{l}\text { Ko mangwana acho wakazoenda } \\
\text { kuchikoro } \uparrow\end{array}$ & $\begin{array}{l}\text { Did you go to school the following } \\
\text { morning? }\end{array}$ \\
\hline $\mathbf{W}$ & Ehe ndakaenda & Yes, I went. \\
\hline $\mathbf{I}$ & Yes Your Worship & \\
\hline
\end{tabular}


Table 4: The form of address 'Your Worship'

\begin{tabular}{|l|l|l|}
\hline Speaker & SL utterances/Interpretations & English gloss \\
\hline $\mathbf{P}$ & Was this in the same spare bedroom & \\
\hline $\mathbf{I}$ & $\begin{array}{l}\text { Makange muri muspare imwecheteyo } \\
\text { here } \uparrow\end{array}$ & $\begin{array}{l}\text { Was it in the same spare bedroom he } \\
\text { raped you before? }\end{array}$ \\
\hline $\mathbf{W}$ & Ehe & Yes \\
\hline $\mathbf{I}$ & Yes Your Worship & \\
\hline
\end{tabular}

The addition of the form of address 'Your Worship' in the interpreter's renditions in Tables 3 and 4 served as a strategy of attending to 'powerless speech style' which might also be expected to produce a positive impression of the testifying witness thereby enhancing the witness's testimony in terms of trustworthiness. Below, the form of address 'Your Worship' is added onto SL utterances made by the accused persons. Tables 5, 6 and 7 illustrate this:

Table 5: The form of address 'Your Worship'

\begin{tabular}{|l|l|l|}
\hline Speaker & SL utterances/Interpretations & English gloss \\
\hline I & $\begin{array}{l}\text { Wanzwisisa mhosva yauri } \\
\text { kupomerwa } \uparrow\end{array}$ & $\begin{array}{l}\text { Have you understood the allegations } \\
\text { being levelled against you by the state? }\end{array}$ \\
\hline A & Hongu & Yes \\
\hline I & Yes, Your Worship & \\
\hline
\end{tabular}

Table 6: The form of address 'Your Worship'

\begin{tabular}{|l|l|l|}
\hline Speaker & SL utterances/Interpretations & English gloss \\
\hline $\mathbf{M}$ & Uhu Anything else & \\
\hline I & Pachine zvimwe & Anything else you would like to ask? \\
\hline A & Ndingangoti hapachina zvimwe & I can say there is nothing else to ask \\
\hline I & I think that is all, your worship & \\
& & \\
\hline
\end{tabular}


Table 7: The form of address 'Your Worship'

\begin{tabular}{|l|l|l|}
\hline Speaker & SL utterances/Interpretations & English gloss \\
\hline $\mathbf{M}$ & $\begin{array}{l}\text { To start with accused, were you ever } \\
\text { served with a copy of this medical } \\
\text { report } \uparrow\end{array}$ & \\
\hline $\mathbf{I}$ & $\begin{array}{l}\text { Wakambotaridzwa here kana kupiwa } \\
\text { gwaro, medical report iyi } \uparrow\end{array}$ & $\begin{array}{l}\text { Were you served or shown this } \\
\text { document, the medical report? }\end{array}$ \\
\hline $\mathbf{A}$ & $\begin{array}{l}\text { Kwete Ndatopuhwa nhasi izvozvi } \\
\text { ndakagara pano }\end{array}$ & $\begin{array}{l}\text { No, I have just been served it today while } \\
\text { seated here }\end{array}$ \\
\hline $\mathbf{I}$ & $\begin{array}{l}\text { No, Your Worship, I only received it } \\
\text { today while I was seated here in court }\end{array}$ & \\
\hline
\end{tabular}

So, when one considers Tables 5, 6 and 7 above, the addition of the politeness forms on SL utterances by the accused persons, although slightly changing the style of the SL utterances, may be argued to be a result of two main reasons. First, it may be argued that as a result of the ritualised courtroom conventions (Hale, 2004; Rigney, 1999) which require certain participants to show respect to the court, the insertion of 'Your Worship' in the interpreter's rendition but which did not occur in the SL utterance, is thus not surprising. Another reason could be the aspect of negotiation of face (Goffman, 1981) in relation to the variable of power and distance. Court interpreters seem to be keenly aware of threats to face and therefore adopt politeness strategies like the inclusion of the politeness form 'Your Worship' to SL utterances in Tables 3, 4 and 5. This strategy is aimed at protecting their own face, as well as the face of others (e.g., the accused and witnesses) and end receivers (e.g., magistrates/public prosecutors).

\section{Emphasising additions featuring completely new information}

Interpreters' TL texts were once again lengthened because they included new information not found in SL texts. In Table 8 below, although the interpreter adds new information in the TL text, she however, filtered out an important part of the propositional content of the SL message i.e. ...don't worry and instead adds ...how clever the court is. The utterance ...don't worry in the magistrate's SL text has an assuring effect that the rights of the accused to a fair trial will be respected. Filtering out this phrase in the TL text and including new information in the form of ...how clever the court is, affects the propositional content of the SL text. This tendency to edit magistrates' and public prosecutors' utterances by interpreters is driven by the motive to enhance intelligibility and effectiveness of the communication process particularly for the benefit of lay interactants $(\mathrm{Ng}, 2013)$.

Table 8: Addition of completely new information

\begin{tabular}{|c|c|c|}
\hline Speaker & SL utterances/Interpretations & English gloss \\
\hline M & Just wait, don't worry & \\
\hline I & $\begin{array}{l}\text { Chimbomirai muone mashandire acho, } \\
\text { kungwara kwakaita dare. }\end{array}$ & $\begin{array}{l}\text { Just wait and see how it works, how } \\
\text { clever the court is }\end{array}$ \\
\hline
\end{tabular}

Per Linguam 2015 31(1):105-120

http://dx.doi.org/10.5785/31-1-635 
The addition of '...kungwara kwakaita dare' (...how clever the court is) in Table 8 above is testimony to the fact that, contrary to the perception that the court interpreter is a 'translating machine' able to produce exact replicas of the original utterances (Mason, 2000), the interpreter instead participated actively in the process of matching the magistrate's utterances to the relevant aspects of context which is a crucial aspect of conversation and the negotiation of meaning (Goffman, 1981).

In Tables 9-12 below, the new information found in the TL texts elaborates on, and emphasises certain pieces of information not found in the SL texts. Some of this new information comes in the form of a clarification question like 'Manzwaka?' (Do you understand) as shown in Table 9 below. The resultant TL texts are therefore much longer than the SL texts as interpreters try to convey the magistrates' and prosecutors' 'mental mode of meaning' (Jacobsen, 2002) to the lay witnesses and defendants, even though the interpreters breach Grice's (1975) maxim of quantity as they provide more information than is required.

Table 9: Addition of completely new information

\begin{tabular}{|l|l|l|}
\hline Speaker & SL utterances/Interpretations & English gloss \\
\hline $\mathbf{P}$ & $\begin{array}{l}\text { We therefore submit that she is likely } \\
\text { to suffer emotional stress }\end{array}$ & \\
\hline $\mathbf{I}$ & $\begin{array}{l}\text { Saka tinoti izvo iye mufakazi akapa } \\
\text { HUCHAPUPU mune chita chevanhu } \\
\text { kudai, munhu angashungurudzike } \\
\text { mupfungwa make pakupupura } \\
\text { kwaanenge achiita mudare Ndoosaka } \\
\text { tichiti anofanirwa kunge asiri pamberi } \\
\text { pevanhu vakawanda Manzwaka } \uparrow \\
\text { Kuitira kuti asununguke pakupa } \\
\text { huchapupu }\end{array}$ & $\begin{array}{l}\text { So we are of the view that if the witness } \\
\text { were to give evidence here in court with } \\
\text { everyone listening, she is likely to suffer } \\
\text { emonal stress when giving evidence in } \\
\text { court that is why we are of the view that } \\
\text { Dhe } \\
\text { that she is free to testify in court }\end{array}$ \\
\hline
\end{tabular}

Table 10: Addition of completely new information

\begin{tabular}{|l|l|l|}
\hline Speaker & SL utterances/Interpretations & English gloss \\
\hline PP & $\begin{array}{l}\text { And did he completely remove your } \\
\text { pant }\end{array}$ & \\
\hline I & $\begin{array}{l}\text { Saka bhurukwa wakaribvisa zvachose } \\
\text { here Kana kuti wakangoridzikisira } \\
\text { kana kuti pane zvimwe zvawakaita } \\
\text { naro }\end{array}$ & $\begin{array}{l}\text { So were the pants removed completely } \\
\text { or hust lowered them or there is } \\
\text { something else he did with the pants }\end{array}$ \\
\hline
\end{tabular}

Table 11: Addition of completely new information

\begin{tabular}{|l|l|l|}
\hline Speaker & SL utterances/Interpretations & English gloss \\
\hline $\mathbf{M}$ & Just wait, don't worry & \\
\hline I & $\begin{array}{l}\text { Chimbomirayi muone mashandire } \\
\text { acho, kungwara kwakaita varungu } \uparrow\end{array}$ & $\begin{array}{l}\text { Just wait and see how it works, how } \\
\text { clever the Englishman is }\end{array}$ \\
\hline
\end{tabular}


Table 12: Addition of completely new information

\begin{tabular}{|l|l|l|}
\hline Speaker & SL utterances/Interpretations & English gloss \\
\hline PP & In what state was it & \\
\hline I & $\begin{array}{l}\text { Yainge yakaita sei Yakange iri } \\
\text { sezvayange yakaita here kana kuti } \\
\text { pane zvayakange yakanganisika kubva } \\
\text { pane zveyange yakaita }\end{array}$ & $\begin{array}{l}\text { In what state were your pants? Were they } \\
\text { in the same state they were before the } \\
\text { rape or there were some changes on the } \\
\text { state of your pants from what they were } \\
\text { originally }\end{array}$ \\
\hline
\end{tabular}

Examples presented in Tables 10,11 and 12 above also feature new information which is not found in the SL utterances. These additions are part of the interpreters' conscious engagement with the SL messages and their attempt to infer and convey the magistrate's or public prosecutor's intentions (Grice, 1975) to the end receiver (witnesses or accused persons). Thus, the inclusion of the additions in Tables 10, 11 and 12 could be argued to be part of court interpreters' judgement that end receivers would not be able to spot implicit information. These additions demonstrate court interpreters' preoccupation with achieving successful communication and their preparedness to violate Hoffman's (1994) guidelines which require verbatim translation, which would otherwise hinder successful communication.

\section{Emphasising additions featuring deixis}

Another type of addition identified is that of deixis (Halliday \& Hassan, 1985). Deixis refers to the phenomenon wherein 'understanding the meaning of certain words and phrases in an utterance requires contextual information' (Halliday \& Hassan, 1985: 211). Information referred to by deixis is that of person, place, and time. All the elements of deixis below were identified in the TL texts but not in the SL texts, and were therefore seen to emphasise information relating to person, place and time. The use of deixis in the examples shown in Tables 13, 14 and 15, coupled with elements of non-verbal communication such as pointing (shown by speech in double parenthesis), could be explained in terms of Grice's (1975) maxim of manner, when the interpreter tries to be as clear and as orderly as possible in what he/she says, and avoids obscurity and ambiguity.

Table 13: Emphasising with deixis

\begin{tabular}{|l|l|l|}
\hline Speaker & SL utterances/Interpretations & English gloss \\
\hline PP & How old was the complainant by then $\uparrow$ & \\
\hline I & $\begin{array}{l}\text { ((Iye wenyu uyu })) \text { anga aine makore } \\
\text { mangani panguva iyoyo } \uparrow\end{array}$ & $\begin{array}{l}\text { How old was this child of yours at that } \\
\text { particular time? }\end{array}$ \\
\hline
\end{tabular}

The emphasis in the phrase 'Iye wenyu uyu...' (This child of yours...) in the interpreter's rendition is not explicitly found in the public prosecutor's question. The use of the personal pronoun 'Iye' and the demonstrative pronoun ' $и y u$ ' coupled with pointing as a non-verbal activity is the interpreter's strategy to avoid ambiguity or even obscuring the referent in the public prosecutor's question. The same explanation also holds for examples shown in Tables 
14 and 15 below:

Table 14: Emphasising with deixis

\begin{tabular}{|l|l|l|}
\hline Speaker & SL utterances/Interpretations & English gloss \\
\hline $\mathbf{M}$ & $\begin{array}{l}\text { I notice you have a document which } \\
\text { you are holding Is it the defense } \\
\text { outline or what } \uparrow\end{array}$ & \\
\hline $\mathbf{I}$ & $\begin{array}{l}\text { Mune chipepa chamuinacho } \\
((\text { ichocho })) \text { Chineyi } \uparrow\end{array}$ & $\begin{array}{l}\text { You have that document on your person, } \\
\text { what is contained in it? }\end{array}$ \\
\hline
\end{tabular}

Table 15: Emphasising with deixis

\begin{tabular}{|l|l|l|}
\hline Speaker & SL utterances/Interpretations & English gloss \\
\hline PP & $\begin{array}{l}\text { In formulating that opinion, the State } \\
\text { has considered the relationship } \\
\text { between the witness and the } \\
\text { accused... natural father and } \\
\text { daughter. }\end{array}$ & \\
\hline I & $\begin{array}{l}\text { Pakusvikawo pakutaura kwakadaro, } \\
\text { vana muchichisi vaonawo hukama } \\
\text { huri pakati ((penyu imi musungwa } \\
\text { nemwana iyeye) mumhan'ari uyu }\end{array}$ & $\begin{array}{l}\text { In formulating that opinion, the state has } \\
\text { taken into consideration the relationship } \\
\text { between you the accused and this } \\
\text { particular child, the complainant, who is } \\
\text { your biological daughter }\end{array}$ \\
\hline \begin{tabular}{l} 
kuti mwanasikana wenyu chaiye \\
\hline
\end{tabular}
\end{tabular}

The examples in Tables 14 and 15 above demonstrate a uniform and consistent use of elements of deixis by the interpreters, aimed at achieving successful communication as they attempted to render SL messages in as clear and unambiguous a form as possible.

\section{Emphasising additions enhancing witness testimony}

The additions in Tables 16 and 17 demonstrate that there is 'a tendency for court interpreters to smooth out witnesses' testimony, and hence enhance their testimonies'. In this way, Morris (1995: 19) observed that speakers' hesitations, unfinished sentences, grammatical mistakes, slips of the tongue and other speech defects, which Hoffman (1994: 14) expect be reproduced by the court interpreter 'even at the risk of the interpreters themselves sounding incompetent', were treated by the court interpreters 'both on a personal level and according to the status of the speaker' (Morris, 1995: 39). 
Table 16: Enhancing witness testimony

\begin{tabular}{|l|l|l|}
\hline Speaker & SL utterances/Interpretations & English gloss \\
\hline PP & Then what happened & \\
\hline I & $\begin{array}{l}\text { Chiyi chakazoitika } \\
\text { Wushure kwaizvozvo ndakazoti } \\
\text { kuma..., tingangoti kumathree> } \\
\text { ndatopedza hangu washeni, ndikati } \\
\text { <aah, mwana aita sei> ndikatogeza } \\
\text { Kumashure kwokugeza paye, mwana } \\
\text { ndopaakabva auya }\end{array}$ & $\begin{array}{l}\text { After that, I decided around about... } \\
\text { <let's say around 3 p.m., > when I was } \\
\text { done with my laundry, and said <aah, } \\
\text { what could be holding back this child> } \\
\text { but I went on and took a bath after which } \\
\text { the child arrived }\end{array}$ \\
\hline I & $\begin{array}{l}\text { Around three o'clock, after I had } \\
\text { finished my laundry, I decided to take } \\
\text { a bath and that is when the child came }\end{array}$ & \\
\hline
\end{tabular}

Table 17: Enhancing witness testimony

\begin{tabular}{|l|l|l|}
\hline Speaker & SL utterances/Interpretations & English gloss \\
\hline A & Aah, $<$ ndinozviramba $>\circ$ & Aah, $<$ I deny the charge $>\circ$ \\
\hline I & I deny the charge & \\
\hline
\end{tabular}

Although the witness's testimony in Table 16 is characterised by hesitations and disfluences, these non-verbal features are not captured in the interpreters' rendition. This is evidence that interpreters sometimes smooth out the speech styles of courtroom participants depending on who the speaker is. The obvious covering up of the non-verbal features of communication in the interpreter's rendition above, although serving to enhance the witness's testimony, may potentially leave out certain aspects of non-verbal communication important in witness evaluation and the trial process. In Table 17, the interpreter's rendition also seems to enhance the accused's speech style. The interpreter converts what appears to be an uncertain denial into a firm denial, thus potentially affecting the trial process. Although the interpreters' behaviour in Tables 16 and 17 above could be seen as a violation of Grice's (1975) maxim of quality where one is expected to be truthful, the kind of impact these additions might have is what (Pym, 2008) refers to as 'low-risk' additions as they do not significantly impact on the intended message, that is, denying the charge, communicated in Table 17.

\section{Down-toning additions}

The additions in this category have a reverse function compared to the category of emphasising additions, because they serve to down-tone or decrease the force of the utterance, or part of the utterance, in the SL. The interpreter may down-tone by including one or more items in the TL texts which were not present in the SL text, as explained below: 
Additions identified under this category appeared to function as hedges. In Tables 18 and 19 below, the interpreters' preferred word forms which express uncertainty down-play the force of the SL utterance. The verbs mungachigara in Table 18 and mungachibuda in Table 19, not available in SL texts, down-tone the force of the magistrates' utterances as indicated below:

Table 18: Down-toning with hedges

\begin{tabular}{|l|l|l|}
\hline Speaker & SL utterances/Interpretations & English gloss \\
\hline $\mathbf{M}$ & $\begin{array}{l}\text { Very well, thank you Take your seat } \\
\text { accused }\end{array}$ & You may take your seat \\
\hline I & Mungachigara zvenyu pasi & \\
\hline
\end{tabular}

Table 19: Down-toning with hedges

\begin{tabular}{|l|l|l|}
\hline Speaker & SL utterances/Interpretations & English gloss \\
\hline $\mathbf{M}$ & $\begin{array}{l}\text { Very well, thank you (.) Please step } \\
\text { down. }\end{array}$ & \\
\hline $\mathbf{I}$ & $\begin{array}{l}\text { Mungachibuda henyu panze } \\
\text { muchazodaidzwazve kana tichikudai }\end{array}$ & $\begin{array}{l}\text { You may go out and you will be called } \\
\text { back if there is need }\end{array}$ \\
\hline
\end{tabular}

The additions identified in Tables 18 and 19 appeared to function as modal verbs or hedges. The interpreters in the above exchanges preferred word forms which express uncertainty thereby down-playing the force of the SL utterance. Saying 'Take your seat accused' is obviously different in force to saying 'You may take your seat' (Table 18). For Gibbons (1993:100), 'modality can either be understood in terms of directness/indirectness hence 'Take a seat' is more direct than 'You may take a seat' or in terms of embedding information within a modal verb frame ('Could you tell us what the colour of the car was?' is more polite than 'What was the colour of the car?')'. In the above interpreters' renditions, the preferred modality reduced the coerciveness of the magistrate. Although the magistrates' SL utterances are different in terms of coerciveness to the interpreters' renditions, they nevertheless have the same communicative intention.

\section{Down-toning additions with an impact on non-verbal aspects of SL messages}

Related to the above are additions which affect the way witnesses present their answers. These additions highlight the fact that it is not only the content of the answer that is important when forming an impression of a witness, but also the way such information is presented. This is what is commonly referred to as speech style, register or form (Berk-Seligson, 1999; Hale, 2004; O'Barr, 1982). Non-verbal elements of communication are important in this regard.

Hale (2004: 112) points out that, while the 'locutionary point of an utterance remains intact, the illocutionary force is likely to be reduced' if aspects of speaker style, including nonverbal elements, are not accurately rendered. In the courtroom, the consequences of even 
relatively subtle pragmatic changes introduced by non-verbal aspects in the interpreting process can be significant.

In Tables 20 and 21 below, the focus is on probing interpreters' TL texts in terms of whether they rendered pragmatically correct interpretations both in terms of the propositional content and style of the message (Moeketsi \& Wallmach, 2005). Aspects of non-verbal communication found in SL texts, such as hesitations, reduced speaking speed and volume, which may be regarded as being at the micro level and therefore peripheral, are nevertheless important aspects of courtroom interactions and hence the courtroom reality (Hale \& Gibbons, 1999). According to Hale and Gibbons (1999: 211), 'two layers of reality are manifested in the courtroom: that of the court itself, the courtroom reality, and that of the events under examination in the case, the external reality'. Hale and Gibbons (1999: 213) observe that, while interpreters tend to faithfully interpret language referring to the external reality, 'there are consistent and significant changes in their interpreted representation of the courtroom reality'. Such changes in non-verbal features of SL texts may, for instance, have significant influences on evidence, and ultimately the outcome of the trial, as illustrated below.

Table 20: Down-toning with non-verbal elements of communication

\begin{tabular}{|c|c|c|}
\hline Speaker & SL utterances/Interpretations & English gloss \\
\hline M & How do you plead $\uparrow$ to the charge & \\
\hline $\mathbf{I}$ & $\begin{array}{l}\text { Munoti chii } \uparrow \text { nenyaya yamakatarisana } \\
\text { nayo Munoibvuma kana kuti } \\
\text { munoiramba mhosva iyi }\end{array}$ & $\begin{array}{l}\text { How do you plead to the charge you are } \\
\text { facing Do you plead guilty to the charge } \\
\text { or you deny the charge } \uparrow\end{array}$ \\
\hline $\mathbf{A}$ & (...hhh) Handiizivio & (...hhh) I do not know ${ }^{\circ}$ \\
\hline $\mathbf{I}$ & I deny the charge & \\
\hline
\end{tabular}

Table 21: Down-toning with non-verbal elements of communication

\begin{tabular}{|l|l|l|}
\hline Speaker & SL utterances/Interpretations & English gloss \\
\hline A & (...hhh) Aah handiizivi & $(\ldots$ hhh $)$ Aah I deny the charge \\
\hline I & 1 deny the charge & \\
\hline
\end{tabular}

What Tables 20 and 21 illustrate is the fact that interpreters may significantly change nonverbal features of SL texts in their interpreted representation of the courtroom reality. Whereas the 'machine notion' of the interpreter would expect the interpreter to convey the message in terms of 'what is said' and 'how it is said' (Hoffman, 1994: 19), the interpreters in the above consistently ignored the non-verbal aspects of the SL utterances. The reason could be that the interpreters regarded the non-verbal aspects as superfluous and without an effect on the TL message, and thus not warranting inclusion in their renditions. However, altering non-verbal aspects of utterances has been seen to have an impact on the message and the delivery of justice (Hale, 2002). 


\section{Down-toning additions with an impact on the accused's credibility and rights}

In this category are down-toning additions which arise from the addition of verbal and nonverbal elements on SL texts which have an effect on threatening the defendant's face and hence their credibility and rights in the trial process. Approaching the pragmatics of interpreting from the perspectives of politeness and negotiation of face, Mason and Stewart (2001) compared two very different events - cross-examination of a Spanish-speaking witness in the O.J. Simpson trial in the United States and interviews by immigration officials of illegal Polish immigrants. Mason and Stewart (2001: 64) are able to show that the 'inherently face-threatening nature of the events themselves (the witness whose credibility is being undermined, the immigrant who is about to be deported) leads to a great deal of facework in the speech of the questioner and the interviewee alike'. The conclusion Mason and Stewart (2001: 59) draw from these triadic speech events which inherently contain a degree of threat to face is that 'face-threatening acts are frequently modified in the act of translating, irrespective of the style of interpreting adopted'.

In Table 22 below, the point of contestation is the verb 'kuverenga' which (to read). The interpreter alters the accused's response 'I cannot read in English' to 'I cannot read Your Worship' which, although protecting the magistrate's face, threatens the accused's face by making the accused less sophisticated, as this makes him completely illiterate and hence less credible.

Table 22: Down-toning which affects the credibility and rights of the accused

\begin{tabular}{|l|l|l|}
\hline Speaker & SL utterances/Interpretations & English gloss \\
\hline I & Hamugoni kuverenga $\uparrow$ & You cannot read $\uparrow$ \\
\hline A & Nechirungu handigoni & I cannot read in English \\
\hline I & I cannot read Your Worship & \\
\hline
\end{tabular}

The interpreter's rendition above has an effect of down-toning the accused's defence. The accused person said 'Nechirungu handigoni' (I cannot read in English) but the interpreter renders it as 'I cannot read Your Worship'. If someone is illiterate in English it does not make them illiterate in all languages. Similarly, the interpreter in Table 23 below misinterprets the SL text by adding some non-verbal features which cast doubt and uncertainty to the magistrate's question and thus threaten the rights of the defendant to a fair trial. Although the interpreter seems to view such aspects as part of the speaker's intention, the inclusion of these verbal and non-verbal features certainly makes the magistrate's question powerless (BerkSeligson, 1990), as shown in the interaction in Table 23. 
Table 23: Down-toning which affects the credibility and rights of the accused

\begin{tabular}{|l|l|l|}
\hline Speaker & SL utterances/Interpretations & English gloss \\
\hline $\mathbf{M}$ & $\begin{array}{l}\text { Now, what do you intend to do Do } \\
\text { you want to be allowed your three } \\
\text { days notice or do you waive your } \\
\text { right to notice } \uparrow\end{array}$ & \\
\hline I & $\begin{array}{l}\text { Saka iwewe uri kuda kuti upuhwe } \\
\text { mazuva matatu iwayo okuriwona here } \\
\text { kana kuti uri kungoti hako <haa-a } \\
\text { kodzero yokuriona mazuva matatu } \\
\text { hangu handineyi nayo, ingoriisayi } \\
\text { henyu pamberi pedare> }\end{array}$ & $\begin{array}{l}\text { So do you want to be allowed your three } \\
\text { days' notice to study the exhibit or you } \\
\text { are just saying < well, ah I can ignore } \\
\text { that right, just go ahead and admit it } \\
\text { before the court> }\end{array}$ \\
\hline
\end{tabular}

The extract in Table 23 above shows that interpreters added some features of powerless speech in the form of language which expresses uncertainty by reducing speaking speed in their interpretations, thereby weakening the accused's defence. This is shown when the interpreter renders the message as '<haa-a kodzero yokuriona mazuva matatu hangu handineyi nayo, ingoriisayi henyu pamberi pedare > ' $<$ well, ah I can ignore that right, just go ahead and admit it before the court $>$ ). This rendition, apart from expressing uncertainty, has an effect on the rights of the accused as it strips the accused person of his right to notice.

\section{DISCUSSION}

The emphasising and down-toning additions identified in this paper could be ascribed to the special nature of the court interpreting process, as the additions were motivated by reasons which can be broadly viewed as falling under two dimensions, which are courtroom conventions and interpreters' concentration on achieving successful communication. Although some of the emphasising and down-toning additions could be attributed to interactional dynamics in the courtroom characterised by complex face-works and unequal power-play between participants, requiring certain participants to behave in a certain way and observe certain courtroom conventions, the majority of the categories of emphasising and down-toning additions identified above could be attributed to the interpreters' obsession with conveying speaker meaning; doing so to a point when they either emphasise or downplay the SL's propositional content and style. In other words, it is possible to argue that the interpreters included these additions based on their intuitive judgment that end receivers would not be able to identify the presence of implicit information, but would be able to infer it once it was identified.

\section{CONCLUSION}

The article identified and discussed the various types of emphasising and down-toning additions, and interpreters' motives for including these additions. The article argued that the presence of additions in the interpreters' target texts could be explained by reference to court interpreters' obsession with matching SL speakers' utterances to relevant aspects of context and with ensuring the retrievability of speaker meaning. This behaviour provided evidence of the interpreters' awareness of the importance of pragmatics in court interpreting. In this way, the interpreters' renditions as confirmed by my findings support the hypothesis that court interpreters are always conscious of the need to convey the speakers' meaning in full. They 
would even overstep ethical guidelines to achieve successful interaction. In conclusion, the court interpreters in this investigation were not mere language robots, simply relaying language products from one language into another. Rather, they actively participated in the interactions in order to reach their primary goal of successful communication. The article therefore makes a significant contribution to the debate on interpreters' role perception by advocating a move towards a more holistic account of dialogue interpreting encounters in which all features are taken into account so that the interpreter's role is better appreciated.

\section{REFERENCES}

BERK-SELIGSON, S. 2002. The bilingual courtroom: court interpreters in the judicial process. Chicago: University of Chicago Press.

BERK-SELIGSON, S. 1999. The impact of court interpreting on the coerciveness of leading questions. Forensic Linguistics, 6(1):30-56.

COTTERILL, J. 2003. Language and power in court. New York: Palgrave Macmillan.

DU BOIS, JW. 1993. Transcription design principles for spoken discourse research. Pragmatics, 1(1):71-106.

FELTOE, G. 1993. Phrasebooks for interpreters. Harare: Government Printers.

GIBBONS, J. 1993. Questioning in common law criminal courts. In Gibbons, J \& MT Turell (Eds), Dimensions of forensic linguistics. Amsterdam: John Benjamins. 115-130.

GOFFMAN, E. 1981. Forms of talk. Oxford: Basil Blackwell.

GRICE, HP. 1975. Logic and conversation. In Cole, P \& JL Morgan (Eds), Syntax and semantics 3: speech acts. New York: Academic Press. 41-58.

HALE, S. 2002. How faithfully do court interpreters render the style of non-English speaking witnesses' testimonies? A data-based study of Spanish-English bilingual proceedings. Discourse Studies, 4(1):25-47.

HALE, S. 2004. The discourse of court interpreting: discourse practices of the law, the witness, and the interpreter. Amsterdam: John Benjamins.

HALE, S \& J GIBBONS. 1999. Varying realities: patterned changes in the interpreter's representation of courtroom and external realities. Applied Linguistics, 20(2):203-220.

HALLIDAY, MAK \& R HASSAN. 1985. Cohesion in English. London: Longman.

HOFFMAN, G. 1994. A guide to interpreters in judicial proceedings. Harare: Government Printers.

HORN, LR. 2010. The expression on negation. Berlin: Walter de Gruyter.

JACOBSEN, B. 2002. Court interpreting and pragmatic meaning. Paper delivered at Sixth International Forum on Legal Translation and Court Interpreting 'Legal Translators and Court Interpreters: Rights, Duties and Needs', Paris, France, 12-14 June 2002.

JEFFERSON, G. 2002. Is 'no' an acknowledgment token? Comparing American and British uses of (+)/(-) tokens. Journal of Pragmatics, 34:1345-1383.

MASON, I. 2000. Models and methods in dialogue interpreting research. In Olohan, M (Ed), Intercultural faultlines. Research models in translation studies I. Textual and cognitive aspects. Manchester: St. Jerome Publishing. 221-234.

MASON, I \& STEWART, M. 2001. Interactional pragmatics: face and the dialogue interpreter. In Mason, I (Ed), Triadic exchanges. Manchester: St Jerome. 51-70.

MOEKETSI, R. 1999. Discourse in a multilingual and multicultural courtroom: a court interpreters' guide. Pretoria: Van Schaik. 
MOEKETSI, R \& K WALLMACH. 2005. From spaza to makoya! A BA degree for court interpreters in South Africa. The International Journal of Speech, Language and the Law, 12(1):77-108.

MORRIS, R. 1995. The moral dilemma of court interpreting. The Translator, 1(1):25-46.

NG, E. 2013. The atypical bilingual courtroom: An exploratory study of the interactional dynamics in interpreter-mediated trials in Hong Kong. Unpublished Doctor of Philosophy thesis, Aston University.

O'BARR, WM. 1982. Linguistic evidence: language, power and strategy in discourse analysis. London: Academic Press.

PYM, A. 2008. On omissions in simultaneous interpreting: risk analysis of a hidden effort. In Hansen, G, A Chesterman \& H Gerzimisch-Arbogast (Eds), Efforts and models in interpreting and translation research: a tribute to Daniel Gile. Amsterdam: John Benjamins. 76-88.

RIGNEY, AC. 1999. Questioning in interpreted testimony. Forensic Linguistics, 6(1):83-108.

THOMAS, J. 1995. Meaning in interaction: an introduction to pragmatics. London: Longman.

\section{BIOGRAPHICAL NOTE}

Paul Svongoro is a $\mathrm{PhD}$ student in the Translation/Interpreting Studies Department of the School of Literature, Language and Media at the University of the Witwatersrand. His research interests are in the fields of court interpreting, corpus-based interpreting studies and discourse analysis.

E-mail: psvongoro@yahoo.com, $\underline{604684 @ \text { students.wits.ac.za }}$ 